\title{
Breast Cancer Clinical TNM Finding v7
}

National Cancer Institute

\section{Source}

National Cancer Institute. Breast Cancer Clinical TNM Finding v7. NCI Thesaurus. Code C88364.

A clinical finding about one or more characteristics of breast cancer, following the rules of the TNM AJCC V7 classification system. TNM clinical findings are based on information obtained prior to the first definitive treatment through physical examination, diagnostic imaging, endoscopy, biopsy or laboratory testing. 